\title{
DEVELOPING PERFORMANCE MEASUREMENT MODEL OF MOSQUES
}

\author{
Umi Khabibah, Ratno Agriyanto \& Dessy Noor Farida \\ Universitas Islam Negeri (UIN) Walisongo Semarang \\ Jl. Walisongo No 3-5, Semarang 50185, Jawa Tengah, Indonesia \\ Email:umikhabibah11101@gmail.com; ratnoagriyanto@walisongo.ac.id; \\ dessy_nf@walisongo.ac.id*
}

\begin{abstract}
The main objective of this research is to find the performance measurement model of mosques in Ngaliyan District. The performance measurement model is adopted from the performance measurement model for organizations profit. This study uses mosque resources, management processes, and mosque performance as research variables. Mosque resources are grouped into mosque management resources (ta'mir), financial resources, and mosque facilities. Process management consists of stewardship management, financial management, and planning management. while the mosque's performance is shown through the implementation of religious activities and religious social services. The survey is limited to jami' mosques in Ngaliyan District which are listed in SIMAS-Kemenag RI (Mosque Information System of Ministry of Religious Affairs of Republic of Indonesia) 2019. By purposive sampling, there are 36 valid samples for the analysis. Path analysis was applied to analyse the data. The results of this research using quantitative method showed that were significant influences between resource and mosque performance with management processes as the mediating variables. The findings from this study will be useful for mosque stakeholders such as mosque administrators, donors, congregations, and religious authorities who are directly affected by mosque performance.
\end{abstract}

Keywords: Management Processes; Mosque; Performance; Resource

\section{ABSTRAK}

Tujuan utama dari penelitian ini adalah untuk mengetahui model pengukuran kinerja masjid di Kecamatan Ngaliyan. Model pengukuran kinerja diadopsi dari model pengukuran kinerja untuk laba organisasi. Penelitian ini menggunakan sumber daya masjid, proses manajemen, dan kinerja masjid sebagai variabel penelitian. Sumber daya masjid dikelompokkan menjadi sumber daya pengelolaan masjid (ta'mir), sumber keuangan, dan fasilitas masjid. Manajemen proses terdiri dari manajemen kepengurusan, manajemen keuangan, dan manajemen perencanaan. Sedangkan kinerja masjid ditunjukkan melalui penyelenggaraan kegiatan keagamaan dan bakti sosial keagamaan. Survei dibatasi pada masjid jami di Kecamatan Ngaliyan yang terdaftar dalam SIMAS-Kemenag RI (Sistem Informasi Masjid Kementerian Agama Republik Indonesia) 2019. Secara purposive sampling terdapat 36 sampel yang valid untuk dianalisis. Analisis jalur diterapkan untuk menganalisis data. Hasil penelitian dengan menggunakan metode kuantitatif menunjukkan bahwa terdapat pengaruh yang signifikan antara sumber daya dan kinerja masjid dengan proses manajemen sebagai variabel mediasi. Temuan dari studi ini akan bermanfaat bagi pemangku kepentingan 
masjid seperti pengurus masjid, donatur, jemaah, dan otoritas keagamaan yang secara langsung terpengaruh oleh kinerja masjid.

Kata kunci: Proses Manajemen; Mesjid; Kinerja; Sumber Daya

\section{INTRODUCTION}

Indonesia is a country with a predominantly Muslim population. Muslims in Indonesia who dominate the territory of Indonesia are directly proportional to the number of mosques as a house of Muslims worship. The Mosque Information System (SIMAS) from the Ministry of Religious Affairs (Kemenag) has shown that there are 741,991 mosques and mushollas in Indonesia with various typologies (simas.kemenag.go.id).

Hasibuan a researcher anh the author of the book Empowerment of Mosques in The Future states that mosques are buildings that are closely related to Muslims, surrounding environment, community environment, and leadership (Aryani, 2015). Mosques have a strategic position for Muslims as an effort to make personal and Islamic society. Hence the mosque must be properly functioning in a broad sense, not a narrow sense-as viewed by the society in general - that is only for praying in congregation.

Mosques in the days of Rasulullah had various tasks. Quba Mosque as the first mosque that was built by the Prophet Muhammad, in addition to functioning as a place of worship, also served as a place to gather Muslims. Besides that, the mosque also served as a place to announce important matters pertaining to the life of the Muslim community, a place to settle issues of the country and society, as a place of education and information center, and to be a residence for science seekers (Ahlus Suffah) (Gazalba, 1994). The mosque is now unable to function as a mosque in the time of Rasulullah, but the mosque began to show performance to function outside the religious activities. (Aryani, 2015) suggests that whether it is realized or not, the current mosque not only serves as a place of worship, but also tends to make new movements by enabling the mosque as a center of culture and muamalat, education center, marriage and even sightseeing spots.

A mosque is a religious nonprofit organization that is based as an organization or public agency because it gains a major income from community contributions. The Law No. 14 of 2008 defines the public agency as an executive, legislative, judicial or other entity whose functions and duties are related to the conduct of the state. Some or all of the funds are from the state budget (APBN), regional government budget (APBD) or nongovernmental organizations. Since the sources are from the APBN and/or the APBD, community contributions and/or overseas mosques as part of the Law No 14 year 2008 are expected to apply the law. The people's fund donated to the mosque through infaq, charity or waqf should be used to maintain the existence of the mosque by maintaining its prosperity.

The Minister of Religious Affairs of Republic of Indonesia (Kemenag RI) through the Directorate General of Community Guidance (Ditjen Bimas) 
in the period 2015-2016 has given the development assistance/rehabilitation to 584 mosques throughout Indonesia. In 2015, the houses of worship facilitated by Ditjen Bimas were 437 mosques and musholla in total, which consist of 344 units of mosques and 93 units of musholla. In 2016, the houses of worship facilitated were 333 mosques and mushollas consisting of 240 units of mosques and 93 units of mushollas.

The provision of development assistance/rehabilitation of houses of worship by the Ministry of Religious Affairs of Republic of Indonesia is the embodiment of the mosque's development program in order to increase the efforts of Islamic religious affairs and sharia cultivation. The assistance given to the house of worship (including the mosque) has a long-term impact on which the management of the mosque is expected to empower the assistance that has been given by making the mosque central to Muslims. Therefore, as a form of accountability for the assistance that has been given to the mosque, the mosque committee (ta'mirs) are expected to demonstrate improved performance and show that the objectives of the mosque are in the process of achievement (Rahman \& Yusof, 2015).

Jami' mosque is one of the most widely found mosque typology in Indonesia. Kemenag through the website of SIMAS noted that there are at least 203,981 jami' mosques in Indonesia. Jami' mosque is a mosque which is located at the level of village/kelurahan which majority of the building of mosque is financed by local self-government. Thus, the operation of the mosque in order to reach its prosperity will depend on the contributions of the society. Jami ' mosque is a rural mosque that is located at the static mosque level until the mosque is actively seen from the side of its management. Jami' mosque relies heavily on donations from the surrounding community as its main stakeholders. The help of the government is very little found in this mosque typology. The great reliance on help from society can be the main reason why performance measurement is needed as a means of public accountability.

Lack of attention to the management of the mosque, can be a latent danger in the continuity of mosque management. It is proven from some cases of misappropriation of mosques funds that occurred lately. At the end of 2018, on 5 November 2018 the chairman of Masjid Yayasan in Palopo managed to corrupt the mosque grants as much as 5 billion rupiah. Before the case, in July 2018, Subiyanto, mosque ta'mir of Pakuwon Mall Surabaya embezzle 266 million from mosque infaq.

The above circumstances triggered an increase in the need for a performance measurement especially the mosque ta'mirs who have been trusted by the community to manage the Islamic worship house. In the management of the mosque's religious organization, in order to gain public trust, the manager should take responsibility for what has been done in managing the mosque (Al Muddatstsir, Kismawadi, \& Farida, 2018). Performance measurement is important to measure the success rate of an organization in achieving its objectives (Baihaqi, 2015). The measurements 
will see how much success you have achieved compared to your planned program or target (Agriyanto, 2015).

Performance measurements applied to non-profit organizations can be adopted from performance measurements in profit-based organizations that take the aspects of resources, processes, and outputs into consideration to determine the effectiveness and efficiency of performance (Rahman \& Yusof, 2015). The management professionally applied by the mosque also can be measured from various aspects of the actual aspects and activities (embodied in the financial statements) and how the activity is conducted (e.g. effectiveness and quality production). Based on some of the performance measurement models above, the study intends to develop the design of the mosque's performance measurement model by considering the aspects of resources, process management, and output as a tangible form of performance outcomes. The mosque as a public organization engaged in the religious field has a distinctive management pattern, so that the performance measurement of the mosque also requires proper modification.

\section{LITERATURE REVIEW}

\subsection{RESOURCE BASED VIEW THEORY}

Resource-based theory emerged since the 1960s as an effort to find factors that influence strategic choices in business competition (Khotimah, 2017). Resource Based Theory (RBV) states that the basis of the main competitive advantage of a company is located on tangible assets or intangible assets (Wernerfelt, 1984). RBV provides an overview of the company's ability to provide a sustainable competitive advantage when resources are processed into valuable and unimitable products. This view is supported by (Peteraf, 1993) stating that to transform short-term needs into sustainable needs, the company resources must be heterogeneous and untransferable.

The competitive advantage owned by the mosque's religious organizations can be described in two aspects. The first is organizational credibility. Miller (2002) mentions that the products offered by religious organisations (supernatural compensators) are abstract and cannot be seen. The mosque supplier or ta'mir cannot even know for certain whether the activities provided are able to improve the quality of the congregation. Based on the generally prevailing market assumption, suppliers who cannot guarantee the quality of their products will experience failures. This assumption cannot be applied in mosques as religious organizations.

The competitive advantage of mosques cannot be seen from the product but the credibility of its religious organization. The credibility of religious organizations can be identified through the indicator of mosque ta'mir commitments that include; mosque ta'mir does not rely on financial compensation from the worshippers, mosque ta'mir orients to the service that is able to be provided to the worshippers and the intensity of worshippers. 
Secondly, it cannot be imitated. Each mosque has a different historical background. These background differences can be a resource that other mosques cannot emulate. Traditional religious ceremonial practices that are still preserved by mosques can also be other unimitated resources (Miller, 2002)

\subsection{MOSQUE PERFORMANCE}

The definition of performance is an overview of the level of achievement of the program activities or policies in realizing the goals, objectives, vision, and mission of the organization that are written in the strategic planning of an organization (Moeheriono, 2012). Moeheriono (2012) states that performance comes from the word "to perform" which means: (1) conducting, exercising, executing, (2) doing something that is expected by a person or machine, fulfilling or carrying out the obligation of an intention or votive, (3) executing or perfecting responsibilities, (4) performance or performance capabilities also have a broad meaning, not only about the results of the organization's performance, but also how the activities in achieving that goal.

Nawawi mentions important aspects to consider before establishing performance measurements that are performance indicators. Hadari said that the performance indicators in the organizational environment are divided into five elements: (1) the quantity of work achieved, (2) the quality of work achieved, (3) the time period to produce such performance, (4) the presence in activities, (5) ability to cooperate (Baihaqi, 2015).

Performance measurement indicators used in organizations whose main activities provide services are as follows; (a) productivity indicators are indicators that focus on the number of jobs completed within a predetermined period of time, (b) utilization rates are indicators that indicate the amount of services available used, (c) time targets are the indicators that show the average time required to complete a certain number of jobs, (d) volume of services e.g. number of home repairs completed, (e) demand/service provision i.e. indicator that shows comparison number of service units with request for service.

Performance measurements of public sector organizations - including mosques-are performed to fulfill three meanings. First, public sector performance measurements are meant to help improve organizational performance. Secondly, public sector performance measures are used to measure resource usage and decision making. Thirdly, public sector performance measures are intended to realize public accountability and improve institutional communication or organization. The measurement of the mosque performance can be seen through the performance of the mosque in both financial and nonfinancial aspects. Financial aspects are demonstrated through periodic financial statements. The non-financial aspect is demonstrated through activities or religious programs organized by mosques such as the intensity of prayer in congregation, the commemoration of Islamic holidays, religious education, religious lectures, charity activities and other community services (Fauzi, Suharjo, \& Syamsun, 2016). 


\subsection{PROCESS MANAGEMENT}

Process is a management section that refers to the activities of organizations that convert resources into outputs in the form of products or services; while the performance management process is the process by which the company manages its performance in line with its strategies and objectives. Suparman (2013) describes process in the Islamic context and draws the conclusion that human life with all the dynamics and resources can achieve the maximum benefits when cultivated (manufactured).

The process elements used in performance can be measured through two key indicators namely (1) performance management and (2) organizational culture (Sillanpaa, 2011). Performance management is a management style in managing performance-oriented resources that perform an open and sustainable communication process by creating a shared vision and a strategic and integrated approach as a driving force to achieve organizational objectives.

Performance management has five key elements: required tasks, organizational actors (human resources), delegation of tasks, task execution sequences and performance accountability (Chrisman, Chua, Massis, \& Minola, 2016). Task delegation allows leaders to foster an employee's sense of the entity in which it works. In the context of the mosque organization, the task delegation can be realized through the division of job description to the manager of the mosque equipped with the tasks schedule. The tasks achievement can be announced through the information board or announcement directly in Friday prayers.

The second factor involved in the process is organizational culture (Inayah, Agriyanto, \& Warno, 2018). A strong organizational culture will be reflected in the behavior of member organizations (Rizki, Agriyanto, \& Dessy Noor Farida, 2019). The organizational culture according has four significant functions in the organization. These four functions are (1) identifying membership, (2) raising commitments, (3) strengthening organizational value, (4) and regulating behavior. The mosque as a nonprofit religious organization is expected to have a culture of organization that is appropriate with sharia principles (Simarmata, 2018).

\subsection{RESOURCES}

Resources are all types of input resources used in a given process to produce output. Rahman \& Yusof (2015) categorize resources into tangible resources and intangible resources. Tangible resources include financial assets and physical assets. The financial asset for the mosque is derived from the mosque's source of funds. Mosques need much fund to be able to prosper the mosque. A large source of funds is expected to produce various mosques activities.

Human resources are regarded as one of the resources that play an important role in achieving organizational success. The success of an organization depends on the ability of human resources in carrying out their duties and functions. Human beings are always active and dominant in every 
activity of the organization because human beings as planners, actors, and determinants of achievement of the organizational objectives (Samsuni, 2017).

The individual productivity in the preparation of reports and administrations used for strategic decision making of the organization will be influenced by the development of competency of human data sources (Adi, Saputra, Ekajayanti, \& Anggiriawan, 2018).

\subsection{HYPHOTHESIS DEVELOPMENT}

\subsubsection{The Influence of resources on mosque performance}

Performance is an overview of the level of achievement of an activity program or policy in realizing the goals, objectives, vision, and mission of the organization that is written in the strategic planning of an organization. Organizational performance according to resource-based theory or known as resource-based view (RBV) depends on the resources it belongs to. Wernerfelt (1984) through his research stated that company performance can be measured through the resources owned by the company Companies that have strategic resources (valuable, rare, inimitable, nonsubstitutable) can maintain their existence and have a competitive advantage compared to companies with non-VRIN resources.

Suardhika (2012) conducted research on the Resource Based View integration model to determine competitive strategies and maximize business performance. I Nengah's research was carried out on SMEs that produce export commodities and are listed in the list of exporters in Bali. The study found that strategic resources and entrepreneurial orientation had an impact on improving the performance of these SMEs.

The realization of resources in the context of mosques can be seen from the ability of the mosque ta'mir and fund source. The mosque that has a ta'mir with a capability to retain its prosperity is demonstrated through good performance. Mosques that have a large source of funds are expected to demonstrate better performance compared to mosques that have a regular source of funds. Based on the arguments elaborated above, the hypothesis formulated in this study is:

H1: There is a significant influence of resources on the mosques performance.

\subsubsection{The Influence of resources on process management}

Each mosque has a variety of different resources. Resources are classified into tangible resources and intangible resources (Galbreath, 2005). Tangible resources include financial assets and physical assets. The financial asset for the mosque is derived from the mosque's source of funds. Mosques need much fund to be able to prosper the mosque. A large source of funds is expected to produce various mosque activities. Other tangible resources are physical assets that can be seen from the facilities that the mosque can provide. 
Intangible resources can be seen from personal capabilities that can process inputs into outputs. Companies that are effectively able to process human resources (knowledge) owned will obtain various benefits such as labor cost reduction, infrastructure, as well as increased company efficiency, effectiveness, innovation, and customer service (Chang, Lin, Chang, Lin, \& Ling-hsing, 2015). In the context of mosque management, the most important resources are mosque ta'mirs.

The differences in the resources owned by each organization will create a difference in the organization's management process. Organizations with diverse resources have more complex management in maximizing resource utilization. Likewise, organizations that have reliable human resources can also produce a diverse work innovation. Therefore, the hypothesis can be formulated as follows:

$\mathrm{H} 2$ : There is a significant influence of the resources and process management on the mosque

\subsubsection{The effect of process management on mosque performance}

The resources owned by the company will be valuable when managed and regulated with good management. Success or whether the organizational objectives are achieved depends on the management of human-created processes as human resources that play an active role in the organization (Samsuni, 2017).

Process management becomes a tool for organizations to process the resources owned. The company value will only be formed when the resources owned by the company are managed, manipulated precisely based on the organization's climate (Sirmon, Hitt, Ireland, \& Texas, 2007). Mosques as one of the religious organizations that have various resources will improve the performance when managed with the right management. Based on the above arguments, the hypothesis can be formulated as follows:

$\mathrm{H} 3$ : There is a significant influence of process management on mosque performance.

2.5.4 The influence of resources on the mosque's performance is mediated by process management

Proper and professional management of resources becomes an important aspect of achieving the organization's performance. This assumption denied the assumption stating that the resource had a direct effect on the organization's performance. Simamora (2016) conducted research on the influence of capability and environmental turbulence on corporate strategies and its impact on university. This research was conducted at the university in Kopertis area III Jakarta. Virgo finds that the capability of the environment turbulence that becomes university's resources affects indirectly on the university's performance through corporate strategy.

Mosques have different resource capacities. The management of mosque resources can professionally improve the performance of mosques. The abilities of the mosque managers are to find, acquire, cultivate, and 
empower the mosque's resources to be an influential aspect of the mosque's performance determination. Based on the assumptions above, the hypothesis can be formulated as follows:

H4: There is a significant influence of resources on the performance of mosques with mosque management as the intermediary variable.

The following theoretical conceptual framework is derived from a research by Rahman \& Yusof (2015) and Sillanpaa (2011).

Figure 1. Theoretical Framework

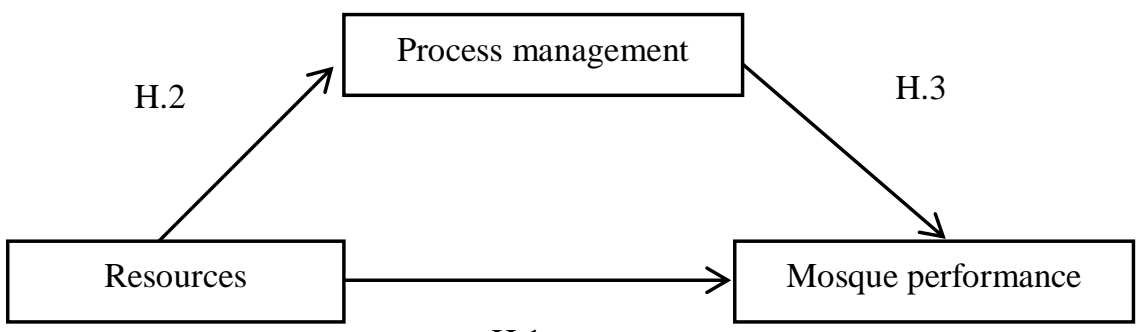

H.1

Based on the theoretical framework above, it can be explained that the large number of resources owned by a mosque will directly increase the performance of the mosque (Nasih: 2011; Lin \& Wu: 2014; Simamora: 2016; Ho \& Peng: 2016). Then, the diverse and unique mosque resources require a qualified management process to optimize the benefits of the resources owned by the mosque (Suhardika: 2012)

\section{RESEARCH METHOD}

The sample for this study was taken from the population of the Jami 'Mosque in Ngaliyan District which is registered with the Mosque Information System of the Ministry of Religious Affairs of the Republic of Indonesia (SIMAS Kemenag). The total number of Jami 'mosques in Ngaliyan District is 53 mosques. This study adopted a purposive sampling method. This technique is used because there are a number of Jami mosques that are registered in the Mosque Information System of the Indonesian Ministry of Religion that do not meet the standards set by the Directorate General of Islamic Community Guidance at the Ministry of Religion of the Republic of Indonesia. By using the above purposive sampling, a total of 36 Jami 'mosques in Ngaliyan District were used as samples.

A set of questionnaires and interviews were used by researchers to collect data in the field. Furthermore, researchers used path analysis to analyze data.

The types of data used in the study are primary data and secondary data. Primary data is the original data collected by researchers using certain instruments that have been prepared and modified by the researchers to 
answer the proposed research questions (Lijan, 2014). The primary data source used by researchers came from questionnaires that were disseminated by the researchers in mosques in Ngaliyan District.

Ngaliyan district has a different social culture. One of the causes of this difference is the difference in the area where the community lives in Ngaliyan District. People living in residential areas tend to have a more modern social culture than people who live in rural areas or villages in general. The difference in social culture also affects the management of mosques in the neighborhood of each region. Ngaliyan Subdistrict is a representative illustration for observing the typology of Jami 'mosque management in communities with modern social cultures and communities with traditional social cultures. The secondary data were derived from the website of the mosque information system (SIMAS), Ministry of Religious Affairs and organizational structure in the mosques.

\subsection{RESEARCH VARIABLES}

\subsubsection{Resources}

Resource is defined as all input resource types used in a certain process for generating output. The mosque resources in this research are interpreted in forms of the mosque management motivation, the satisfaction of ta'mir performance, the commitment of the ta'mir to the mosque, the financial resources of mosques and mosque facilities (Fauzi et al., 2016). Resources as independent variables will be measured using the Likert scale accompanied by structured interviews using predefined interview guidelines.

\subsubsection{Process Management}

Process management is a management section that refers to organizational activities that transform resources into outputs in the form of products or services. Process management will be converted into three main processes, namely daily management process, financial management, and program planning (Alim, 2010). The process management is measured using Likert scale.

\subsubsection{Mosque Performance}

The mosques performance is the result of the mosque management process. The measurement of the mosque performance was adopted from the information of the mosque management standards issued by Ditjen Bimas Kemenag in 2014 which categorizes the performance of mosques into the following criteria; prayer intensity in congregation, Islamic Great Day commemoration, religious education and knowledge Program, charity activities, management results, financial expenses, and congregational services. 


\subsection{DATA ANALYSIS TECHNIQUES}

The techniques of analysis used are description analysis and path analysis. A descriptive analysis is the statistics used to analyze the data by describing or depicting the collected data as it is without intent to make a conclusion or generalization (Sugiyono, 2016). formula:

The percentage of the descriptive analysis method uses the following

Description

$$
\%=\mathrm{n} / \mathrm{N} \times 100 \%
$$

$\mathrm{n}=$ Number of respondents reply scores

$\mathrm{N}=$ Number of ideal answer score

$\%=$ Percentage rate

Then the following criteria are arranged:

$$
\begin{array}{ll}
\% \text { lower }(\% \mathrm{r}) & =1 / 5 \times 100 \%=20 \% \\
\% \text { higher }(\% \mathrm{t}) & =5 / 5 \times 100 \%=100 \% \\
\text { Distance } & =100 \%-20 \%=80 \% \\
\text { Number of classes } & =5 \text { classes } \\
\text { Interval criteria } & =80 \%: 5=20 \%
\end{array}
$$

Table 1. Criteria for Interval Values

\begin{tabular}{cc}
\hline Interval Criteria & Criteria \\
\hline $84 \%<\%$ score $\leq 100 \%$ & Very good/Always \\
\hline $68 \%<\%$ score $\leq 84 \%$ & Good/very often \\
\hline $52 \%<\%$ score $\leq 68 \%$ & Pretty good/frequent \\
\hline $36 \%<\%$ score $\leq 52 \%$ & Not good/rare \\
\hline $20 \%<\%$ score $\leq 36 \%$ & Not very good/never \\
\hline
\end{tabular}

The next analysis is path analysis. Test path analysis is the use of a regression analysis to assess the causality relationship between variables predetermined based on the theory (Ghozali, 2013). Path analysis is used to test the research with the intervening variables (mediators). SPSS21 was used as an assistive device to test path analysis. Here is the model analysis of the line used to test the relationship between the source power and the performance of the mosque and whether the source power against the mosque's performance is mediated by the process management variables.

Based on the line analysis model of the above, it is stated that the relationship is based on the theory that the resource has a direct influence on the performance of the mosque (P1). Nevertheless, the resource also has an indirect influence on the mosque's performance from the resource to the new process management $(\mathrm{P} 2)$ to the performance of the mosque (P3).

In each dependent variable, there will be an arrow to the dependent variable. This arrow serves to explain the number of variances that are not 
otherwise described by the variable. The E1 arrow to process management shows the number of process management variance that is not described by the resource, Magnitude e1 $=\sqrt{ }\left(\left(1-\mathrm{R}^{\wedge} 2\right)\right.$. While the arrows from E2 to the performance of the mosque show the number of performance variance of mosques that cannot be explained by the process management variables and resources and magnitude $\mathrm{e} 2=\sqrt{ }\left(\left(1-\mathrm{R}^{\wedge} 2\right)\right.$.

Track analysis is the development of multiple linear regressions. In conducting analysis using a regression with assisted SPSS software, it is necessary to make the equation of regression based on the formulation of hypotheses that researchers have determined:

$$
\begin{gathered}
M P=a+\beta_{2} S D+\varepsilon_{1} \\
K M=a+\beta_{1} S D+\beta_{3} M P+\varepsilon_{2}
\end{gathered}
$$

in which:

$\begin{array}{ll}\text { a } & =\text { Constanta } \\ \text { SD } & =\text { Resources } \\ \text { MP } & =\text { Process management } \\ \text { KM } & =\text { Mosque performance } \\ \text { P1 } & \text { = Resource regression coefficient on the second equation } \\ \text { P2 } & =\text { Regression coefficient of resource on first equation } \\ \text { P3 } & =\text { Regression coefficient of process management }\end{array}$

\section{DATA ANALYSIS AND DISCUSSION}

\subsection{JAMI' MOSQUE OVERVIEW IN NGALIYAN DISTRICT}

Jami' mosques in Ngaliyan District - as recorded in mosque information system of Ministry of Religious Affairs - are 53 mosques spread across 10 sub-districts in Ngaliyan District. Out of 53 mosque, only 36 mosques meet the standard of imarah in the Decree of Director General of Islamic Community Guidance DJ. II/802 Year 2014 as the samples. Here is the detailed list of jami' mosques in Ngaliyan District:

Table 2. List of Jami ' Mosque in Ngaliyan District

\begin{tabular}{clc}
\hline No & \multicolumn{1}{c}{ Mosque Description } & Total \\
\hline 1 & Jami' mosques in Ngaliyan District & 53 \\
\hline 2 & $\begin{array}{l}\text { Mosques that do not meet the standard criteria of mosque } \\
\text { imarah }\end{array}$ & 14 \\
\hline 3 & The mosque displaced by Batang-Semarang toll project & 1 \\
\hline 4 & Mosques outside Ngaliyan District & 2 \\
\hline 5 & $\begin{array}{l}\text { Number of mosques that meet the mosque's imarah } \\
\text { criteria }\end{array}$ & 36 \\
\hline
\end{tabular}

From the table above, it can be concluded that there are 14 mosques that do not meet the standard criteria of jami' mosque. Mosque imarah standard that is not fulfilled include the use of mosques as the place of Friday 
prayers, not serving religious education in the form of TPQ or Madrasah Diniyah, and unavailability of services and equipment for cremation.

\subsection{DESCRIPTIVE VARIABLE RESOURCES}

The resource variable is measured through three indicators, namely the mosque manager motivation, job satisfaction, and a commitment to the mosque. These indicators are developed into 15 questions in which each indicator consists of 5 questions. The resource variable description results can also be seen from the following graph:

Graph 1. Results of a Resource Variable Description

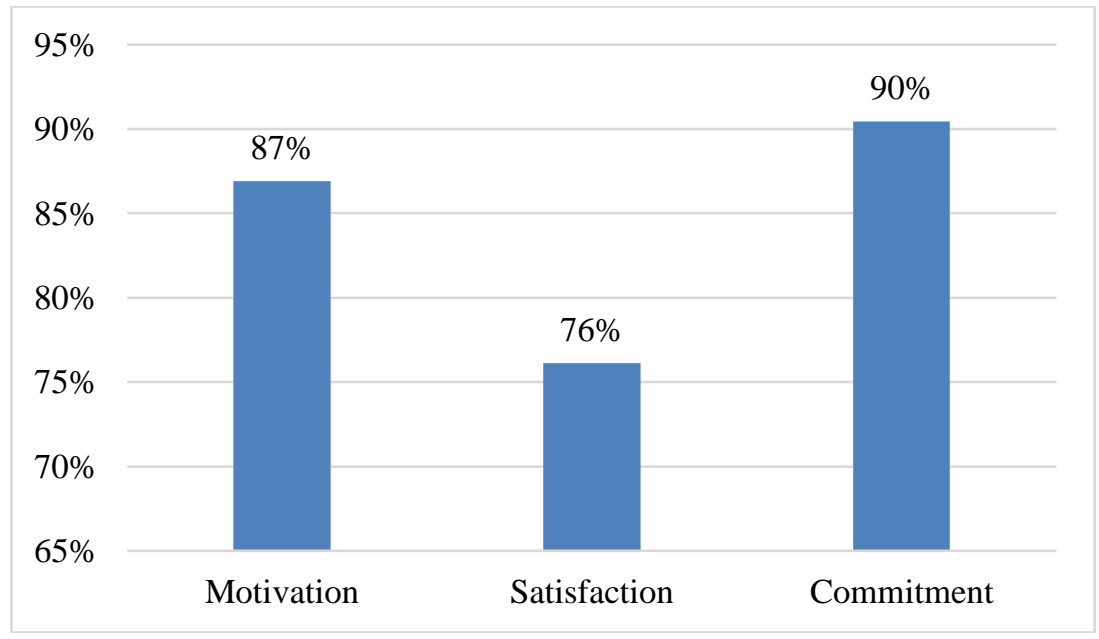

Source: Processed primary data, 2019

Graph 1 explains the motivation indicator that is one of the resource variables resides at intervals of $84 \%-100 \%$ with a value of $87 \%$. These values indicate that the level of the mosque management motivation is categorized very good.

The work satisfaction indicator is at intervals of $68 \%-84 \%$ with a value of $76 \%$. The value shows that job satisfaction is in good category. This value is lower than that of the mosque's motivation at a value of $87 \%$ with very good category.

The mosque's commitment from the number of 36 mosques earns a $90 \%$ percentage. This value is at intervals of $84 \%-100 \%$ with excellent categories. Among the other three indicators, the management's commitment is to get the highest percentage compared to other indicators.

Other indicators of the variable resources are also demonstrated through the average annual income of mosques collected by researchers through interview techniques and documentation. The results showed that the average annual income of the mosque is at the lowest amount of $\mathrm{Rp} 12,000,000.00$ while the highest revenue is $\operatorname{Rp} 750,000,000.00$. 
Facilities owned by jami' mosque is relatively diverse (see appendix). However, there are only two mosques that have organized zakat management, namely Masjid Al Muhajirin Kalipancur and Masjid Al Azhar under Permata Puri housing.

\subsection{DESCRIPTION OF PROCESS MANAGEMENT VARIABLES}

The process management variables are measured through three indicators that are the managers' commitment to the mosque, financial management, and activity planning and the mosque program. The three indicators are described in 12 questions. Based on the table management variable the process gained a percentage of $82 \%$ and was at intervals of $68 \%-84 \%$. This indicates that the process management variables are categorized good. The process management variable description results can be seen from the following graph:

Graph 2. Description of Process Management Variables

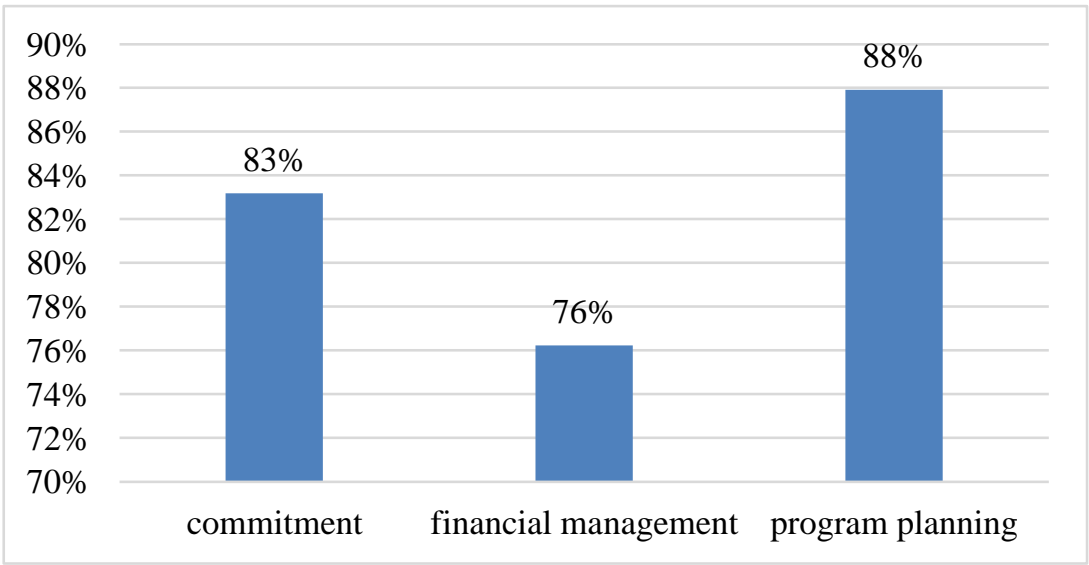

Source: Processed primary data, 2019

Graph 2 above shows that the indicator of the managers' commitment to the mosque earns a percentage of $83 \%$. This value is at intervals of $68 \%$ $84 \%$ so the indicator of commitment to the mosque is categorized at a good level. Financial management gets a lower percentage compared to the mosque's commitment. Financial management gained a percentage of $76 \%$ and was at intervals of $68 \%-84 \%$ or categorized good. Planning programs get a percentage of $88 \%$ and are at intervals of $84 \%-100 \%$. This value indicates that the program planning at 36 mosques in Ngaliyan is categorized very good.

\subsection{DESCRIPTION OF MOSQUE PERFORMANCE VARIABLES}

Graph 3 shows that the majority of jami' mosques in Ngaliyan District very often hold the commemoration of Islamic Day (PHBI). It is seen from the percentage of $81 \%$ on the implementation of PHBI in jami' mosque in 
Ngaliyan District and is at intervals of $68 \%-84 \%$. Religious education gained a smaller percentage than the implementation of PHBI. The implementation of religious education in jami' mosques in Ngaliyan District is at frequent intensity with a percentage value of $66 \%$. This value is at the third interval with a criterion interval of $52 \%-68 \%$. Charity indicators and virtues earn a percentage of $69 \%$. These values are at intervals of $68 \%-84 \%$ so it is categorized as very frequent. It can be concluded that charity and welfare activities are very often done in jami' mosques in Ngaliyan District.

Graph 3. Description of Mosque Performance Variables

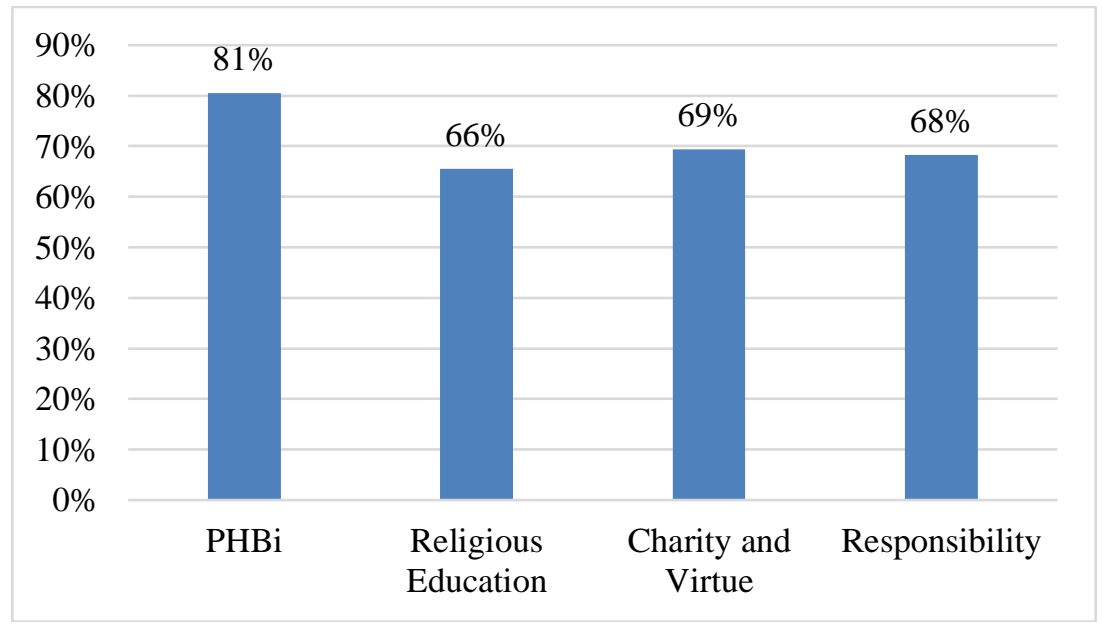

Source: Processed primary data, 2019

The responsibility indicator earns a percentage of $68 \%$. This value is at the third limit interval of 52\%-68\%. It can be concluded that the responsibility of the mosque in the form of mosque idarah management is often done by the mosques.

\subsection{THE INFLUENCE OF RESOURCES ON MOSQUE PERFORMANCE}

The results of the study show that the mosque's resources do not have a direct significant influence on the performance of jami' mosque in Ngaliyan District. It is because the significance value is greater than the specified significance level. SPSS testing showed an unstandardized coefficient beta value of 0.014 and showed a significance value of $>0.05$ at a value of 0.959 then H1 was rejected. Good resource level, either from human resources (ta'mir mosque), financial resources, and adequate facilities, cannot directly affect the performance of the mosque. It is found from the results of a questionnaire that the value of high resources is not directly proportional to the high performance of the mosque.

The interview with the ta'mirs and the caretakers of jami' mosques in Ngaliyan District showed some causes of the absence of influence between the resources and the performance of mosques. First, the regeneration of the 
caretaker is not in accordance with the rules established by the Director General of the Islamic Community Guidance DJ. II/802 Year 2014. The majority of jami' mosque management in Ngaliyan District regenerate in more than 5 years and can be re-elected over two periods. This has an impact on the lack of programs renewal.

Secondly, good human resources are evidenced by the high level of motivation and the commitment of the manager to the mosque is still not synergized because the caretaker still works individually. The paradigm of "as long as it is running" is still found in the management of jami' mosque in Ngaliyan District. Third, relatively high financial resources have not been allocated proportionally to all aspects of the mosque's management, namely the aspect of idarah, imarah, and ri'ayah. The majority of the mosques with relatively high financial resources provide the biggest allocation of funds for development (riayah), while the ratio for other mosque activities is still minimal. The relatively large mosque funds are also not allocated to the Islamic Great Day commemoration. The majority of jami' mosques in Ngaliyan District still ask the community incidentally for the commemoration of Islamic Day events.

The results of this study supported the research results A. Fauzi, Suharjo, and Syamsun (2016) entitled "Influence of financial resources, intangible assets, and competitive advantage that implicates the performance of micro, small and medium enterprises in Lombok." The research also contrasted with previous research conducted by M. Fauzi and Abd (2015) under the title "Performance Measurement Model of Mosque" which states that resources have a significant influence directly against the performance of mosques in Malaysia.

\subsection{LEVERAGE ON PROCESS MANAGEMENT RESOURCES}

The resources in this research model have a significant influence directly on the management of the process at jami' mosque in Ngaliyan District. It is demonstrated by a lesser significance value compared to the specified significance level of 0.008 . It is also seen in the research that mosques that have high levels of resources, whether from human resources or mosque ta'mirs, financial resources, and mosque facilities will have a systematic and complex process management system.

The study supported previous research by Sirmon et al. (2007) entitled "Managing Firm Resource in Dynamic Environments to Create Value: Looking Inside the Black Box" which state that which states that value is created only when resources are properly evaluated, manipulated, and used in the context of the corporate environment. Thus, managing resources appropriately will result in optimizing the use of resources in the context of mosque.

\subsection{THE INFLUENCE OF PROCESS MANAGEMENT ON MOSQUE PERFORMANCE}

The results showed that the process management significantly affected the performance of jami' mosques in Ngaliyan District seen from the significance 
of the testing value of 0.01 which is smaller than 0.05 . It is concluded that the relationship is valid.

The study supported the previous research (Rahman \& Yusof, 2015) entitled Performance Measurement Model of Mosque" and at the same time supported the paradigm proposed by Suparman about discription of the process in the Islamic context in the "reconstruction of the Islamic theology. The Influence of Mosque Resources on Mosque Performance with Mosque Management as the Intervening variable.

The process management in this model of research is the relationship between mosque resources and the performance of jami' mosques in Ngaliyan District. The process management variable has resulted in a resource variable affecting the mosque's performance variables indirectly. It is also demonstrated from indirect influence value of 0.3267 which is greater than the direct influence value of 0.014 .

Process management is a defining factor in the relationship between the resources and the performance of jami' mosques in Ngaliyan District. High resources when managed with proper process management will result in good mosque performance.

The mosque's resources in each jami' mosque in Ngaliyan District which are relatively high can be combined with managerial skills through process management. High human resources are subsequently managed and delegated based on personal ability. Financial resources will also be delegated through proportional tasharruf. The three main aspects of mosque management are the idarah, imarah, and ria'yah aspects of each obtaining a proportional allocation of funds. Thus, the prosperity of the mosque is not only seen from the majesty of the building but also intensified activities in the mosque.

Some of jami' mosques in Ngaliyan District, especially those in residential areas, have implemented a mosque process management system. The mosques are Masjid Al Muhajirin Pasadena, Masjid At-Taqwa Sulanji, and Masjid Al Azhar under Permata Puri. Process management is implemented from the establishment of different organizational structures for each management divisions such as TPQ, Orphanage, LAZIS/LAZISNU, where the divisions are under the mosque.

The management of other processes is also evident in the financial management of the mosques. The three mosques have different treasurers for each division, so the income and expenditure of funds for each deviation is the responsibility of each treasurer. Infaq that is intended for orphanages or TPQ will be accepted and issued for orphanage or TPQ needs. Likewise, with the acceptance of LAZIS and LAZISNU is also transmitted to Mustahik Zakat.

The results of this research in accordance with previous research conducted by (Somjai \& Jermsittiparsert, 2019) Lin and Wu (2014) entitled "Exploring the Role of Dynamic Capabilities in Firm Performance under the Resources based View Framework" and research from Ho and Peng (2016) 
entitled "Managing Resources and Relations in Higher Educations Institutions: A Framework for Understanding Performance Improvement.

This research model can be described through the following flowchart framework:

Figure 6. Result of track analysis

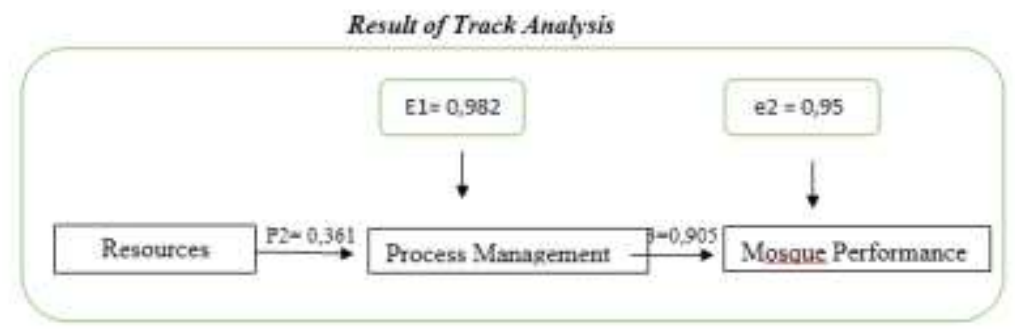

Source: Processed primary data, 2019

\section{CONCLUSION}

This research provides empirical evidence that the resource does not directly affect the performance of jami' mosque in Ngaliyan District because the significance value is greater than the specified significance limit of 5\%. Other causes are the lack of ta'mir mosque regeneration and renewal of mosque programs, human resources are not yet able to synergize and still individual, and the allocation of the mosque's funds are still centered on development.

The resource significantly affects the management of jami' mosque in Ngaliyan District seen from its significance value which is smaller than $5 \%$. This suggests that high and diverse resources require more orderly and more complex process management.

The process management affects the performance of jami' mosque in Ngaliyan District. Good process management and professional will have an impact on improving the performance of jami' mosque in Ngaliyan District. Likewise, if the management of the mosque process is not executed properly, it will have an impact on the performance of jami' mosque in Ngaliyan District.

The Resources have an effect on mosque performance mediated by process management variables. The relatively high resources of the Jami 'mosque in Ngaliyan District can improve the performance of the mosque if it is managed in a professional management. accountability.

The findings from this study will be useful for mosque stakeholders such as mosque administrators, donors, congregations, and religious authorities who are directly affected by mosque performance. Then academically, this research gives a practical contribution to the development of accounting and management science, especially in public accounting studies. 


\section{REFERENCES}

Adi, K., Saputra, K., Ekajayanti, L. G. P. S., \& Anggiriawan, P. B. (2018). Kompetensi Sumber Daya Manusia Dan Sikap Love Of Money Dalam Pengelolaan Keuangan Usaha Mikro Kecil Menengah (UMKM). Jurnal Reviu Akuntansi Dan Keuangan, 8(2), 135-146. https://doi.org/10.22219/jrak.v8i

Agriyanto, R. (2015). Redefining Objective of Islamic Banking; Stakeholders Perspective in Indonesia. Economica: Jurnal Ekonomi Islam, 6(2), 7790. https://doi.org/10.21580/economica.2015.6.2.795

Al Muddatstsir, U. D., Kismawadi, E. R., \& Farida, D. N. (2018). Praktik Akuntabilitas Masjid: Studi Kasus pada Masjid Al-Akbar Surabaya. Economica : Jurnal Ekonomi Islam, 9(2), 207-231.

Aryani, D. (2015). Masjid dan Perubahan Sosial (Kajian Tentang Aktivitas Masjid Baiturrahman Terhadap Perubahan Sosial Masyarakat Perumahan Polri Gowok, Sleman, Yogyakarta).

Baihaqi, I. (2015). Pengembangan Balanced Scorecard untuk Pengukuran Kinerja Organisasi Berdasarkan Tingkat Kepuasan Mahasiswa dalam Layanan Akademik di Fakultas Teknik Universitas Negeri Yogyakarta. Universitas Negeri Yogyakarta.

Chang, C. L., Lin, T., Chang, C. L., Lin, T., \& Ling-hsing, C. (2015). The role of organizational culture in the knowledge management process. Journal of Knowledge Management, 19(3), 433-455. https://doi.org/10.1108/JKM-08-2014-0353

Chrisman, J. J., Chua, J. H., Massis, A. De, \& Minola, T. (2016). Management processes and strategy execution in family firms : from ““ what "" to " how ." Small Business Economics. https://doi.org/10.1007/s11187-016-9772-3

Fauzi, A., Suharjo, B., \& Syamsun, M. (2016). Pengaruh Sumber Daya Finansial, Aset Tidak Berwujud dan Keunggulan Bersaing yang Berimplikasi Terhadap Kinerja Usaha Mikro, Kecil dan Menengah di Lombok NTB. Manajemen IKM, 11(2), 151-158.

Galbreath, J. (2005). Which resources matter the most to firm success ? An exploratory study of resource-based theory. Technova, 25, 979-987. https://doi.org/10.1016/j.technovation.2004.02.008

Gazalba, S. (1994). Masjid Pusat Peribadatan Dan Kebudayaan. Jakarta: Pustaka Al-Husna.

Ghozali, I. (2013). Aplikasi Analisis Multivariate dengan Program IBM 23. Semarang: Badan Penerbit Universitas Diponegoro.

Ho, S. S., \& Peng, M. Y. (2016). Managing Resources and Relations in Higher Education Institutions: A Framework for Understanding 
Performance Improvement. Educational Sciences: Theory \& Practice, 16(1), 279-300. https://doi.org/10.12738/estp.2016.1.0185

Inayah, N., Agriyanto, R., \& Warno, W. (2018). The Role of Spirituality in the Behavior of Sharia Bank Mobile Banking: Evidence from Indonesia. Walisongo: Jurnal Penelitian Sosial Keagamaan, 26(1), 197-224.

Khotimah, K. (2017). Pandangan Berbasis Sumber Daya (RBV) dalam Pembahasan Organisasi Ekonomi. Future: Jurnal Manajemen Dan Akuntansi, 5(1), 31-41.

Lijan, P. S. (2014). Metode Penelitian Kuantitatif. Graha Ilmu: Yogyakarta.

Lin, Y., \& Wu, L. (2014). Exploring the role of dynamic capabilities in fi rm performance under the resource-based view framework. Journal of Business Research, 67(3), 407-413. https://doi.org/10.1016/j.jbusres.2012.12.019

Miller, K. D. (2002). Competitive Strategies Of Religious Organizations. Strategic Change, 456(October 2001), 435-456. https://doi.org/10.1002/smj.234

Moeheriono, E., \& Si, D. M. (2012). Pengukuran Kinerja Berbasis Kompetensi. Jakarta: Raja Grafindo Persada.

Peteraf, M. A. (1993). The Cornerstones of Competitive Advantage: A Resource-Based View. Strategic Management Journal, 14(3), 179-191. https://doi.org/10.4324/9780203847589

Rahman, M. F. B. A., \& Yusof, S. N. S. (2015). Performance Measurement Model of Mosques. Procedia Economics and Finance, 31(15), 26-35. https://doi.org/10.1016/S2212-5671(15)01128-4

Rizki, M. K., Agriyanto, R., \& Dessy Noor Farida. (2019). The Effect of Sustainability Report and Profitability on Company Value: Evidence from Indonesian Sharia Shares. Economica: Jurnal Ekonomi Islam, 10(1), 117-140.

Samsuni. (2017). Manajemen Sumber Daya Manusia. Al Falah, XVII(31), $113-124$.

Sillanpaa, V. (2011). Performance measurement in welfare services : a survey of Finnish organisations. Measuring Business Excellence, 15(4), 62-71. https://doi.org/10.1108/13683041111184116

Simamora, V. (2016). Pengaruh keunikan kapabilitas dan turbulensi lingkungan terhadap strategi korporasi dan dampaknya pada kinerja universitas. Journal of Business Studies, 2(1), 1-16.

Simarmata, J. (2018). Praktek Manajemen Kinerja dan Kinerja Organisasi pada Universitas Batanghari: Peran Budaya Organisasi sebagai Variabel Moderator. Jurnal Manajemen Dan Sains, 3(2), 137-145. 
Sirmon, D. G., Hitt, M. A., Ireland, R. D., \& Texas, A. (2007). Managing Firm Resources In Dynamic Environments To Create Value : Looking Inside The Black Box. Academy of Management Review, 32(1), 273292.

Somjai, S., \& Jermsittiparsert, K. (2019). The trade-offbetween cost and environmental performance in the presence of sustainable supply chain. International Journal of Supply Chain Management. researchgate.net.

Suparman. (2013). Coorporate Social Responsibility: Bentuk Tanggung Jawab Sosial dan Kepedulian Perusahaan dengan Masyarakat. Jurnal Interaksi, 2(1), 69-81.

Wernerfelt, B. (1984). A Resource-based View of the Firm. Strategic Management Journal, 5(June 1982), 171-180. 
